\title{
Effect of active and passive aeration on composting of household biodegradable wastes: a decentralized approach
}

\author{
Prashant P. Bhave ${ }^{1}$ (D) Bhargavi N. Kulkarni ${ }^{1}$
}

Received: 12 February 2019 / Accepted: 3 October 2019 / Published online: 3 November 2019

(c) The Author(s) 2019

\begin{abstract}
Purpose Present work aims at studying the influence of active (using external aerator) and passive (natural) aeration on composting of household biodegradable wastes.

Methods To study the suitability of these reactors to household conditions, continuous loading was carried out for a period of 60 days. Both the reactors were loaded with cooked as well as raw vegetable and fruit waste. Physico-chemical parameters such as temperature, $\mathrm{pH}, \mathrm{C} / \mathrm{N}$ ratio, moisture content, total organic content, Total Kjeldahl Nitrogen and seed-germination parameters such as Germination Index (GI) and Root Length Index (RLI) of the mulch were analyzed at different stages of the composting process.

Results Results confirmed that, although both types of aeration seem to have performed well under continuous loading, the maturation period required for actively aerated reactor was $37.30 \%$ lesser than that of naturally aerated reactor.

Conclusion Active aeration found to be more suitable to household conditions as odor and fly nuisance was relatively less.
\end{abstract}

Keywords Compost reactor $\cdot$ Total Kjeldahl Nitrogen $\cdot$ Germination parameters $\cdot$ Maturation period

\section{Introduction}

Municipal solid wastes (MSW) require prioritized attention and immediate action from authorities, because it has been identified as one of the three main sources of environmental degradation in Asian countries by the World Bank (Letcher and Vallero 2011). Industrialization and urbanization have inadvertently affected solid wastes generation, specially, in metropolitan cities of India, and have made solid waste management (SWM) a consequential issue. There is an interlude between the rate at which solid wastes are generated and are managed; this gap has led to environmental, social and infrastructure problems. Hence, there is an urgent need to address SWM menace. The existing centralized wastes management approach needs integration of different MSW treatment methods based on the waste's composition, for efficient SWM. Since the organic fraction of solid wastes generated in India is 40-50\% (Manual on MSW management India 2016),

Prashant P. Bhave

ppbhave@ci.vjti.ac.in

1 Civil and Environmental Engineering Department, V.J. Technological Institute, H.R. Mahajani Road, Matunga, Mumbai 400 019, India one such method is incorporating decentralized composting, which is well established, simple, and cost effective and has received public acceptance (Diaz et al. 2007).

Since the 1990s, there is a trend towards, smaller, manually operated composting plants at community level initiated primarily by citizens' or non-government organizations (NGOs) and supported by international funds (Furedy 1992). The major components of household wastes are of biodegradable nature, thus, can be efficient for generation of added-value products (example, compost/manure, biogas, digestive slurry, etc.) for sustainable urban habitat development and land restoration programme (Suthar and Singh 2015).

The advantages anticipated from decentralized approach include (a) in combination with primary wastes collection, composting improves precarious wastes situation in the communities, and residents become less dependent on the existing SWM system. (b) Decentralized composting can be operated by an appropriate technology and implemented at reduced investment and operating cost. (c) Manual composting in small, decentralized plant is more easily integrated in the prevailing Indian level of development and socio-economic background, as it requires labor-intensive processes. It also offers new employment opportunities and a source 
of income to the underprivileged in the Indian society. (d) Decentralized composting allows reuse of organic wastes where it is generated, thereby reducing waste quantity to be transported as well as its associated cost and increases waste recycling. (e) Small-scale composting of kitchen and garden wastes is possible under unfavorable cold weather conditions, if sufficient funds are available to incur its construction cost (Zurbrugg et al. 2004; Ravi Kumar et al. 2009; Arrigoni et al. 2018).

Decentralized solid waste management is a system designed to provide habitable and hygienic environment conditions by treating certain amount of wastes at the point of generation. It involves the management of MSW by several small wastes' management centers within the locality (Desai and Shah 2018). In-vessel compost reactors, drum compost reactors, and bioreactors for organic wastes composting are the different compost methods which promote decentralized waste management.

Decentralized compost reactors can be successfully implemented, and time required to convert wastes into compost or soil conditioner, can be reduced, using locally available resources. A lab scale study conducted for in-vessel composting of household wastes using compost accelerator culture which was grown on regional crop jowar (Sorghum vulgare) yielded the good humus that can be used to build up poor physical soil and some basic plant nutrients (Iyengar and Bhave 2006). Continuous thermophilic composting (CTC) of organic fraction of MSW was studied by setting up four bench-scale thermophilic reactors. The compost reactors were placed in incubators and thermocouples were inserted in the compost pile and were linked with recorder. After composting for 14, 16, 18 and 19 days in the four CTC runs, respectively, mature compost products were obtained with quality like or better than which has been stabilized for 28 days (Xiao et al. 2009).

Qualitative analysis of the compost from mechanically and manually operated bioreactors has showed that the compost obtained from both the reactors satisfied almost all quality criteria as per manual on MSW management rules, India (2016) and thus can be used as soil amendment to increase the fertility of soil (Bhave and Joshi 2017).

Wastes segregation at the household levels is a prerequisite for efficient decentralized composting (Manual on MSW management India 2016). Experience survey conducted to learn about waste segregation revealed that urban local bodies (ULBs) in cities such as Bengaluru, Chennai, Delhi, Hyderabad, and Mumbai have achieved waste segregation efficiency of $80-85 \%$ at household levels. Hence, integrating decentralized composting in existing waste management alleviate the existing SWM problem.

Composting is an aerobic, micro-organism-mediated, solid-state fermentation process, by which different organic material are transformed into more stable compounds. The product obtained is the compost, which contributes to the improvement of physical, chemical and microbiological properties of the soil (Sanchez et al. 2017). Aeration rate, temperature, moisture content, and $\mathrm{pH}$ are the important physical factors which affect the stability and maturation of the compost (Guo et al. 2012). Aeration is crucial and inherent component of composting; it provides oxygen needed for aerobic biochemical processes and removes heat, excess moisture and carbon dioxide and other products of decomposition (Shimizu 2017).

Present study aims at analyzing the role of aeration on decentralized composting of organic wastes from the residences. For this purpose, an experimental setup is designed consisting of two compost bioreactors one with active aeration (using external aeration) and another one as a control bioreactor (with natural aeration). The quality of the compost from both the reactors will be studied based on the physico-chemical and seed germination parameters.

\section{Materials and methods}

\section{Experimental setup}

To study the effect of active and passive aeration on composting of household biodegradable wastes, two composting reactors were setup in laboratory. Tapered polyvinyl chloride (PVC) containers of capacity $50 \mathrm{~L}$ were used to accommodate approximately $46 \mathrm{~L}$ of biodegradable wastes loaded over a period of 60 days. The top and bottom diameters of the container were $420 \mathrm{~mm}$ and $300 \mathrm{~mm}$, respectively; height was $475 \mathrm{~mm}$ and thickness of the container was $1.0 \mathrm{~mm}$. One of the designed criteria to choose this size of the container was that the vessel must be urban accommodative without creating problems in the urban residential dwelling units.

A mixing arrangement was provided in the form of central shaft (material of shaft-acrylic) of diameter $35 \mathrm{~mm}$ of with 11 numbers of acrylic fins of thickness $4 \mathrm{~mm}$. These fins were provided at different depths to the central shaft to ensure proper mixing at different levels and length of fins varied according to the tapered shape of the PVC container. To strengthen the reactors for a load of approximately $40 \mathrm{~kg}$ after 60 days, two circular acrylic plates were provided at the bottom of the reactors one with $290-\mathrm{mm}$ diameter and 6-mm thickness, and another with 150-mm diameter and 8 -mm thickness. These plates were placed one above the other and a central hole of diameter $36 \mathrm{~mm}$ was provided in these plates so that the central mixing rod can be placed and supported.

Peripheral aeration was provided through the perforated pipes of 15-mm diameter inserted through 4-mm-thick acrylic top plate at different depths to ensure air supply at different levels. At the base of the both reactor containers, 
six numbers of four 4-mm diameter holes were made around the central rod arrangement for leachate collection and removal. Reactors were mounted on a stand (300 $\mathrm{mm}$ height) and the leachate was collected in a tray provided at the bottom. The dimensions of both the reactors were identical. The only difference was, in actively aerated reactor, a slit of size $5 \mathrm{~mm} \times 5 \mathrm{~mm}$ was provided in central mixing shaft through which aeration pipe was inserted. Details of compost reactor have been explained in Fig. 1.

\section{Household organic waste used for composting}

Food waste was collected from the canteen of V J Technological Institute, Mumbai. To make the composting process user friendly, no prior treatment (like cutting of the wastes, segregation) was carried out for the wastes. However, to simulate the household solid wastes, following approximate proportion of wastes was loaded in both the reactors for composting:

Fig. 1 Details of compost reactor
Cooked food waste: $65 \%$

Vegetable waste: $23 \%$

Fruit waste: $12 \%$.

\section{Loading details}

Both actively and passively aerated reactors were loaded continuously for a period of 60 days. The reactors were loaded with $720 \mathrm{~g}$ of the food wastes four times a week, and fruit wastes and vegetable wastes $(720 \mathrm{~g})$ were loaded into the reactors once every week. To study the effect of sudden loading on the maturity of the compost, the reactors were subjected to shock loading of $2500 \mathrm{~g}$ per reactor at an interval of 15 days.

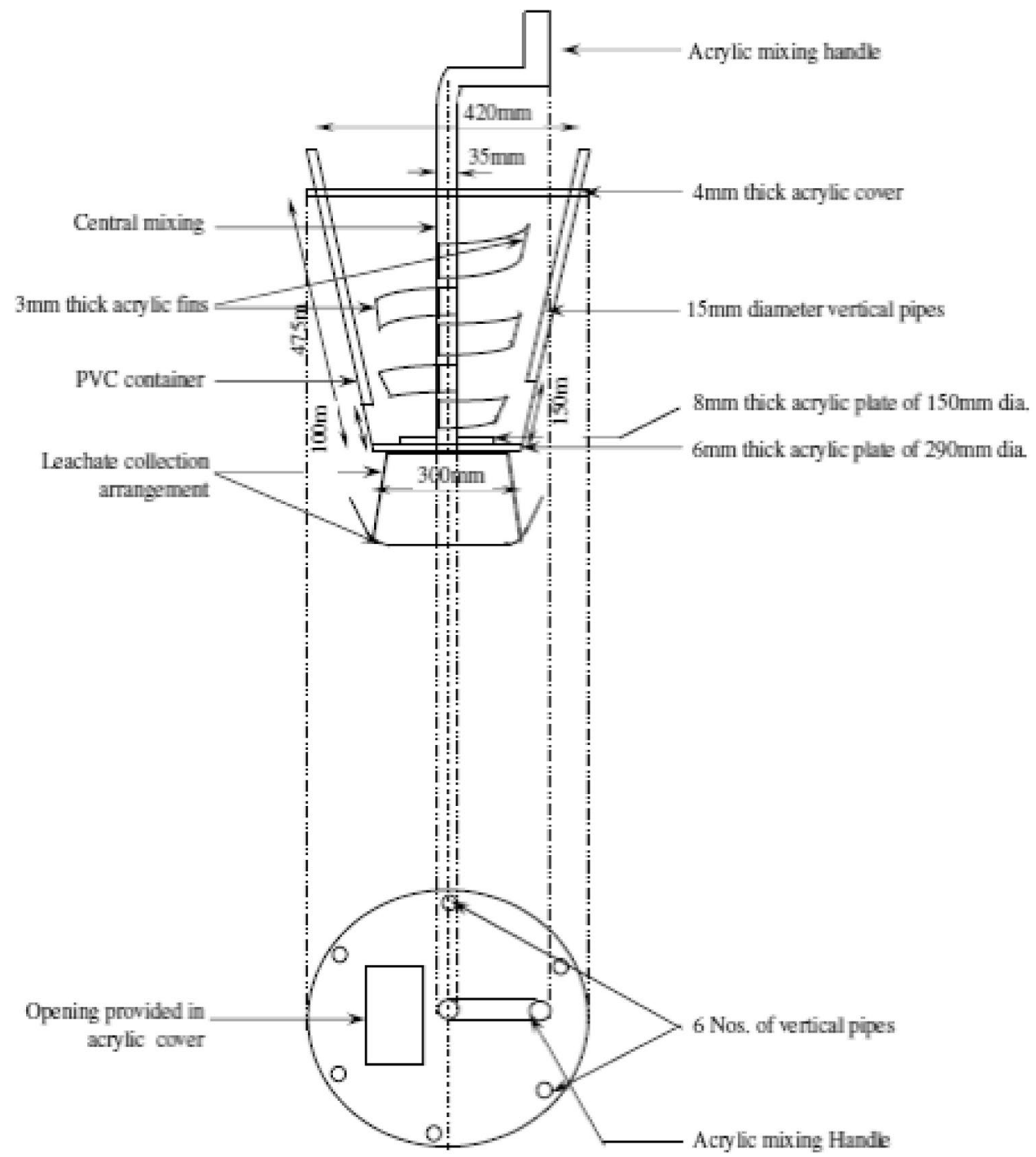




\section{Aeration details}

Passive aeration reactor with passive aeration was subjected to daily mixing of the wastes, and no external aeration was provided.

Active aeration rate of air flow for active aerated reactor was estimated based on the numerical value of air flow rate, $0.021-0.026 \mathrm{~m}^{3} / \mathrm{kg} / \mathrm{h}$ proposed by Schulze (1960) for reactor-type composting. The numerical value of air flow rate considers microbial respiration (oxygen uptake) and key environmental factors (Schulze 1960, 1961). For the total waste load of $42 \mathrm{~kg}$, air flow required was $0.88 \mathrm{~m}^{3} / \mathrm{h}$. Aeration was supplied with intermittent air flow in two cycles. The length of aeration cycle was controlled by the temperature within the composting materials and ranged from 2 to $5 \mathrm{~h}$ per cycle. Intermittent aeration was preferred over continuous aeration as the later can cause gradients within the composting environment leading to excessive drying and permanent cool zones in the area where air enters (Shimizu 2017). Mixing of the wastes was like that of passively aerated reactor.

\section{Physico-chemical parameter determination}

During loading period, moisture content, and total organic carbon were measured once in a week while temperature and $\mathrm{pH}$ were measured every alternate day. Temperature of the compost material in each reactor was monitored using handheld analog thermometer inserted at four different locations and depths (Villar et al. 2016). pH was measured using $\mathrm{pH}$ electrode, waste was mixed with de-ionized water in the proportion of 1:5 and it was stirred and after a settling time of $1 \mathrm{~h}, \mathrm{pH}$ was measured in the liquid phase (Sundberg et al. 2013). Moisture content was assessed using percent dry weight method by drying at $105^{\circ} \mathrm{C}$ to constant weight (Mengistu et al. 2017). During the maturation period, chemical parameters like Total Kjeldahl Nitrogen (TKN) (acid digest) were determined by titrimetric method and total organic carbon by loss on ignition at $600{ }^{\circ} \mathrm{C}$ for $2 \mathrm{~h}$ (Iyengar and Bhave 2006). Total potassium was determined using flame photometry fitted with element specific filters, total phosphate (acid digest) and soluble phosphate (distilled water extraction) using vanadomolybdophosphoric method by employing UV-V spectrophotometer at $420 \mathrm{~nm}$.

Germination parameters, Germination Index and Root Length Index were measured once in a week during maturation period. To determine these parameters, water extracts of compost samples were prepared; mulch was suspended in water in the ratio 1:9 (wet weight/volume) and is mixed for 10-15 min (Wu et al. 2000). After mixing, a contact period of $3 \mathrm{~h}$ was given. The extract was separated from the solids after the settling of the solids at the bottom of the flask.
Germination Index (GI)—ten Triticum aestivum (wheat) seeds were placed in 9-cm diameter petri dish lined with filter paper and $10 \mathrm{ml}$ aliquot of extract at various dilutions was added. Germination of the seeds in 10-ml distilled water was used as control. The petri dishes were incubated in the dark for $72 \mathrm{~h}$ at $25^{\circ} \mathrm{C}$. The percentage of germinated seeds, the length of the sprouts and roots were determined after 3 days. The effect of fertilizer was evaluated by counting the number of germinated seeds and measuring the length of the roots. Germination Index (GI) and Root Length Index (RLI) were calculated by the following equations (Stabnikova et al. 2005):

$\mathrm{GT}=A / B \times 100 \%$,

where GT is germination test, $A$ is the number of germinated seeds for seeds treated by fertilizer and $B$ is the number of germinated seeds in distilled water (control).

$\mathrm{RL}=C / D \times 100 \%$,

where $C$ is the average root length of seeds treated by fertilizer ( $\mathrm{mm})$ and $D$ is the average root length of seeds in distilled water (control) (mm).

The Germination Index (GI) was calculated using following formula (Stabnikova et al. 2005):

$\mathrm{GI}=(A \times C) /(B \times D) \times 100 \%$.

\section{Results and discussion}

\section{Leachate analysis}

The leachate was collected at an interval of 15 days. Various leachate parameters were analyzed during loading and maturation period. It was observed that the leachate collected was rich in oil and fats this was because of two-third the biodegradable waste, which was used for loading, composed of $65 \%$ of cooked food waste. The various leachate parameters analyzed from active $(\mathrm{A})$ and passive $(\mathrm{P})$ reactors are presented in Table 1.

\section{Volume reduction}

Volume reduction was estimated based on the density of biodegradable waste, and for middle-income countries, the density of the wastes varies from 170 to $330 \mathrm{~kg} / \mathrm{m}^{3}$ (Manual on MSW management India 2016); density of $200 \mathrm{~kg} / \mathrm{m}^{3}$ was considered for calculating density of the waste. The volume reduction in active and passive aerated reactors is shown in Table 2.

\section{Temperature}

Variations in temperature of the mulch are an indication of microbial activity during composting and stability of the final organic product (Margaritis et al. 2018). To have a high rate of biodegradation and a maximum microbial diversity, 
Table 1 Analysis of the leachate generated from active (A) and passive $(\mathrm{P})$ reactors

\begin{tabular}{|c|c|c|c|c|}
\hline \multirow[t]{2}{*}{ Leachate parameters } & \multicolumn{2}{|c|}{ Loading period (0-60 days) } & \multicolumn{2}{|c|}{ Maturation period (61-110 days) } \\
\hline & A reactor & $\mathrm{P}$ reactor & A reactor & $\mathrm{P}$ reactor \\
\hline Quantity of leachate (ml) & $422 \pm 72$ & $525 \pm 75$ & $122 \pm 72$ & $170 \pm 75$ \\
\hline $\mathrm{pH}$ & $6.95 \pm 0.45$ & $6.05 \pm 0.55$ & $7.5 \pm 0.5$ & $6.5 \pm 0.5$ \\
\hline Chlorides (mg/L) & $3000 \pm 1500$ & $3750 \pm 1250$ & $1300 \pm 800$ & $2600 \pm 600$ \\
\hline B.O.D (mg/L) & $5600 \pm 600$ & $6750 \pm 450$ & $2150 \pm 650$ & $3450 \pm 550$ \\
\hline C.O.D (mg/L) & $7200 \pm 700$ & $7650 \pm 650$ & $2750 \pm 750$ & $4200 \pm 900$ \\
\hline Total solids (mg/L) & $30000 \pm 3000$ & $33500 \pm 3500$ & $14500 \pm 2500$ & $17500 \pm 2500$ \\
\hline Oil and fats $(\mathrm{gm} / \mathrm{L})$ & $0.495 \pm 0.045$ & $0.525 \pm 0.075$ & $0.275 \pm 0.075$ & $0.400 \pm 0.100$ \\
\hline
\end{tabular}

Table 2 Volume reductions within the reactors

\begin{tabular}{llll}
\hline Reactor type & $\begin{array}{l}\text { Initial volume }\left(\mathrm{m}^{3}\right) \text { of waste } \\
\text { in reactor }\end{array}$ & $\begin{array}{l}\text { Final volume }\left(\mathrm{m}^{3}\right) \text { of waste } \\
\text { in reactor }\end{array}$ & $\begin{array}{l}\% \text { volume } \\
\text { reduction }\end{array}$ \\
\hline Actively aerated reactor & 0.20 & 0.0154 & 92.30 \\
Passively aerated reactor & 0.20 & 0.0305 & 84.75 \\
\hline
\end{tabular}

40

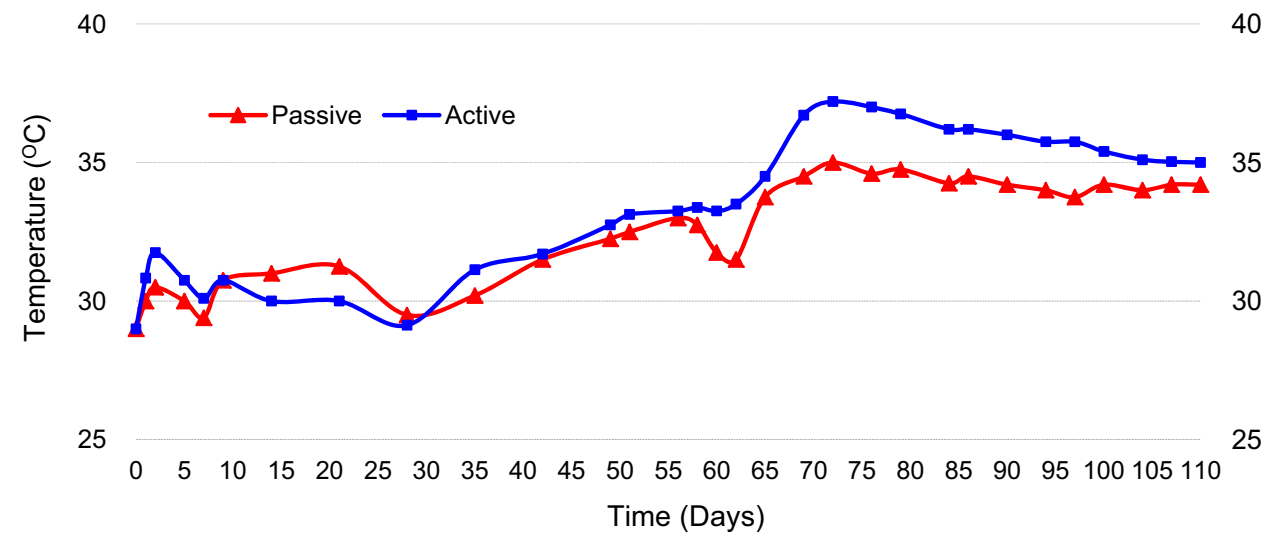

Fig. 2 Variation of temperature within the compost reactors the temperature must range between 30 and $45^{\circ} \mathrm{C}$ (Bertoldi et al. 1988; Finstein et al. 1983; Stentiford 1993). During the maturation period, temperature started increasing in actively aerated reactor and a maximum temperature around $38{ }^{\circ} \mathrm{C}$ was reached and later stabilized at the end of the maturation period to a temperature of $32{ }^{\circ} \mathrm{C}$. The temperature profile of the actively aerated reactor showed that composting process started at ambient temperature (mesophilic range) and progressed to and through a near thermophilic phase, the temperature did not exceed $40{ }^{\circ} \mathrm{C}$. This is attributed two factors, first, in active or forced aerated composting, the dominant heat removal mechanism is evaporative cooling (vaporization of water) which accounts perhaps $80-90 \%$ of the heat removal. In such systems, the contribution of conduction to heat removal may be small (Finstein et al. 1983; Finstein and Hogan 1993) and the second factor being the influence of ambient temperature (Margaritis et al. 2018) which was around $10{ }^{\circ} \mathrm{C}$ (experimental study was carried out during winter season) this coupled with the absence of thermal insulation to the reactors, had significant influence on the temperature developed within the reactors. However, the temperature developed in the active aerated reactor was $38{ }^{\circ} \mathrm{C}$ for 9 days and this was close to the sanitization temperature specifications prescribed by the US Environmental protection agency (USEPA 1999). Temperature variations within the reactors are presented in Fig. 2.

\section{Moisture content}

Optimal moisture content in the starting material varies and is a function of physical state and size of the particles and the composting system used, normally, a $60 \%$ moisture content in the starting material is considered satisfactory (Diaz et al. 2007). During the loading period, substrate moisture content was $83.91 \%$ and $83.20 \%$ in active aerated and passive aerated reactors, respectively. These high values are ascribed to the nature of substrate, and household food waste fraction from MSW may exhibit high moisture content, by up to $70-85 \%$, owing to the nature of the most dominant food waste groups that possess high water content, 
namely fruits and vegetables (Margaritis et al. 2018). Similar moisture content values have been outlined in other research studies (Ma et al. 2016; Margaritis et al. 2018). At the end of the maturation period, the moisture content was $32.19 \%$ in active aerated reactor and $33.43 \%$ in passively aerated reactor. The reported values were higher than the standard range of $15-25 \%$ recommended by FAI (2007), Ministry of Agriculture and Rural Development, India. Changes in moisture content for active and passive aerated compost are demonstrated in Fig. 3.

\section{Total organic carbon (TOC)}

Total organic carbon is an indicator of amount of organic matter present in the compost material (Sharma et al. 2019). Composts from canteen waste have shown high organic matter content (Vazquez et al. 2015). The carbon content in the final product after 5 days sun drying was $36.78 \%$ in actively aerated reactor and $40.12 \%$ in passively aerated reactor, which indicated more time required for the maturation of the mulch in passively aerated reactor. The minimum total organic carbon content prescribed by FCO standards is $16 \%$ and the permissible exceedance limit is $33.30 \%$ (Mandal et al. 2014), the TOC content of compost from active aerated reactor was slightly higher than the FCO standards. Similarly, high TOC concentrations have been reported in study on organic matter stabilization during composting (Francou et al. 2005). Variations of total organic carbon content in compost reactors have been illustrated in Fig. 4.

\section{Germination Index (GI)}

Initially, the GI value for the actively aerated reactor was $51.82 \%$ and for passively aerated reactor it was $44.65 \%$ and these values gradually increased as the maturation phase progressed. A drop in these values was observed when both the reactors were subjected to shock loading. The final GI values were $81.72 \%$ and $71.11 \%$ for the respective reactors. These values showed that the final product obtained from actively aerated reactor was matured and free from phytotoxins (Paredes et al. 2005). The higher values of GI at the end of maturation is due to the higher content of nitrogen in the final product (Margaritis et al. 2018), however, final product from passively aerated reactor required around 2 more weeks for maturation, and variation of Germination Index value for compost reactors during maturation period is presented in Fig. 5.
Fig. 3 Variation of moisture content within the reactors

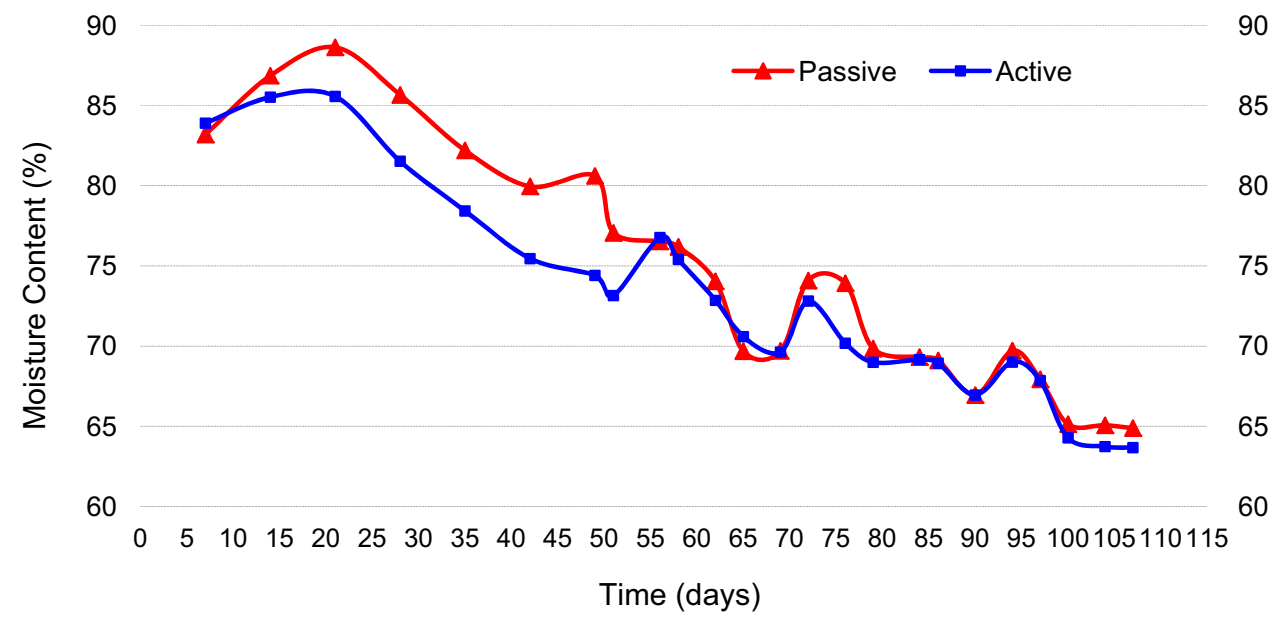

Fig. 4 Variation of total organic carbon content within the reactors
60

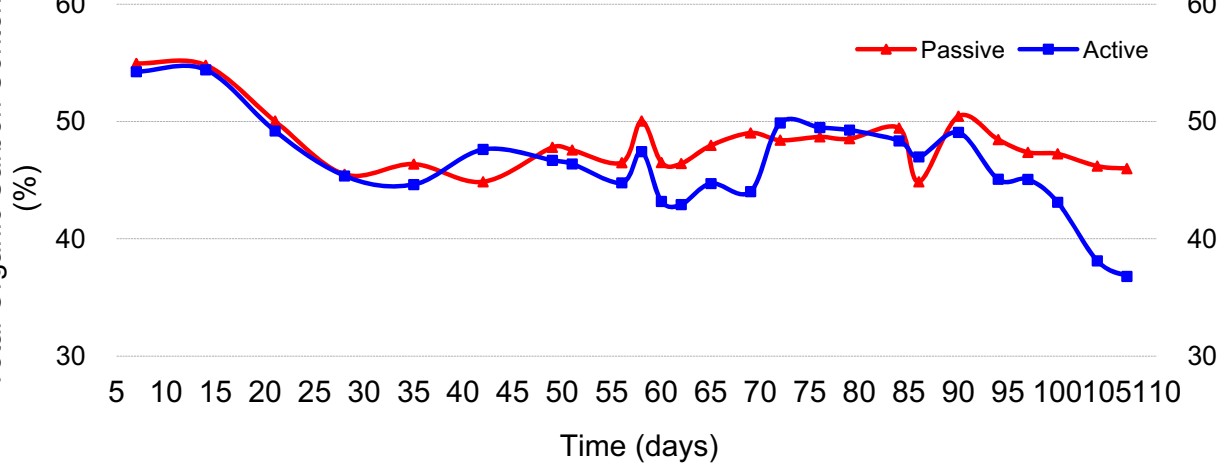


Fig. 5 Variation of Germination Index during maturation period

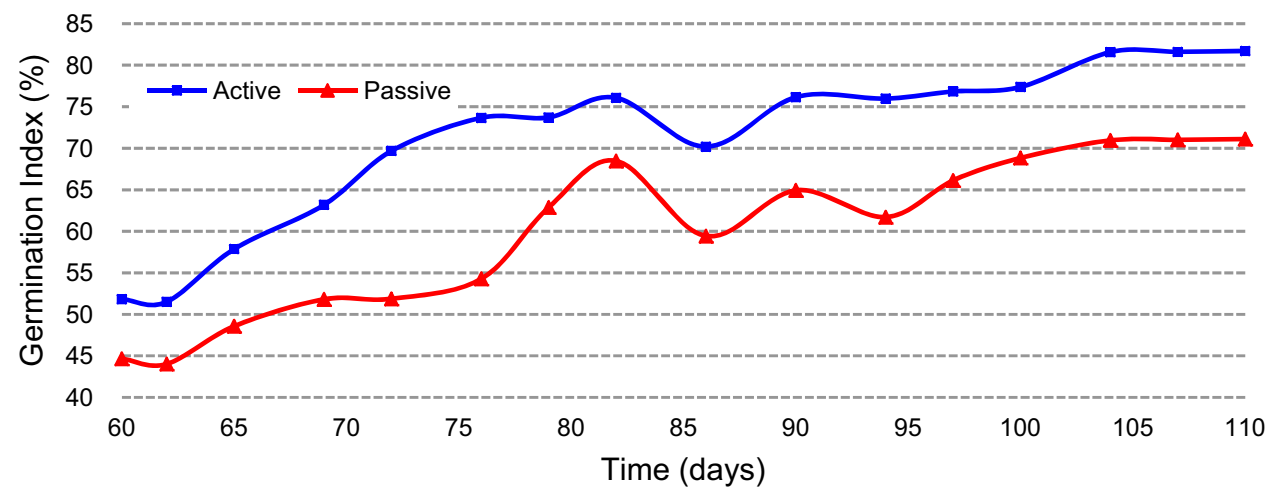

\section{Root Length Index (RLI)}

Alike Germination Index, Root Length Index (RLI) is also an indicator of phytotoxicity and maturity of the compost. Initially, the RLI value for the actively aerated reactor was $54.93 \%$ and for passively aerated reactor, it was $46.89 \%$ and these values gradually increased as the maturation phase progressed, whereas the final RLI values were $83.98 \%$ and $73.02 \%$ for the respective reactors. These values showed that the final product obtained from actively aerated reactor was matured and free from phytotoxins. Final product from passively aerated reactor required around 2 more weeks to mature. Variation of Root Length Index values with time for active and passive aerated reactors have been explained in Fig. 6.

\section{Phosphorus content}

The food waste such as whole wheat bread, potatoes, garlic, and peanuts are rich in phosphorus content and these are very commonly found in Indian household wastes (Haug 1993). Fertilizer control order recommends a range of $1.59-1.80 \%$ for phosphorous content and the threshold value being $0.5 \%$ in compost. During the beginning of the maturation phase, the phosphorus content in active and passive reactors were $0.74 \%$ and $0.61 \%$. This is due to gradual accumulation of phosphorus rich waste within the reactors. During the maturation period, this phosphorus content increased marginally in both the reactors. The final phosphorus content observed was $1.02 \%$ in actively aerated reactor and $0.91 \%$ in passively aerated reactor, which were higher than the prescribed value by FCO. Studies analyzing the chemical parameters of compost from organic waste have recommended a value of $0.3-3.5 \%$ for phosphorus content in matured compost (Haug 1993). Changes in phosphorous content within the reactors during maturation period have been reported in Fig. 7.

\section{Total Kjeldahl Nitrogen (TKN)}

During composting process, microorganisms that are instrumental in breaking down the organic compounds may temporarily tie up all the available nitrogen in their cell structures. As the composting proceeds towards completion, dying off the microorganisms also take place, which then releases the nitrogen making it available to plants again (Haug 1993). The total nitrogen content prescribed by FCO standards ranges from 1.61 to $1.77 \%$ (FAI 2007). The TKN values reported were in accordance with the standards recommended. Initially, the Total Kjeldahl Nitrogen was $0.67 \%$ in actively aerated reactor and $0.69 \%$ in passively aerated reactor. As the maturation phase
Fig. 6 Variation of Root Length Index during maturation period

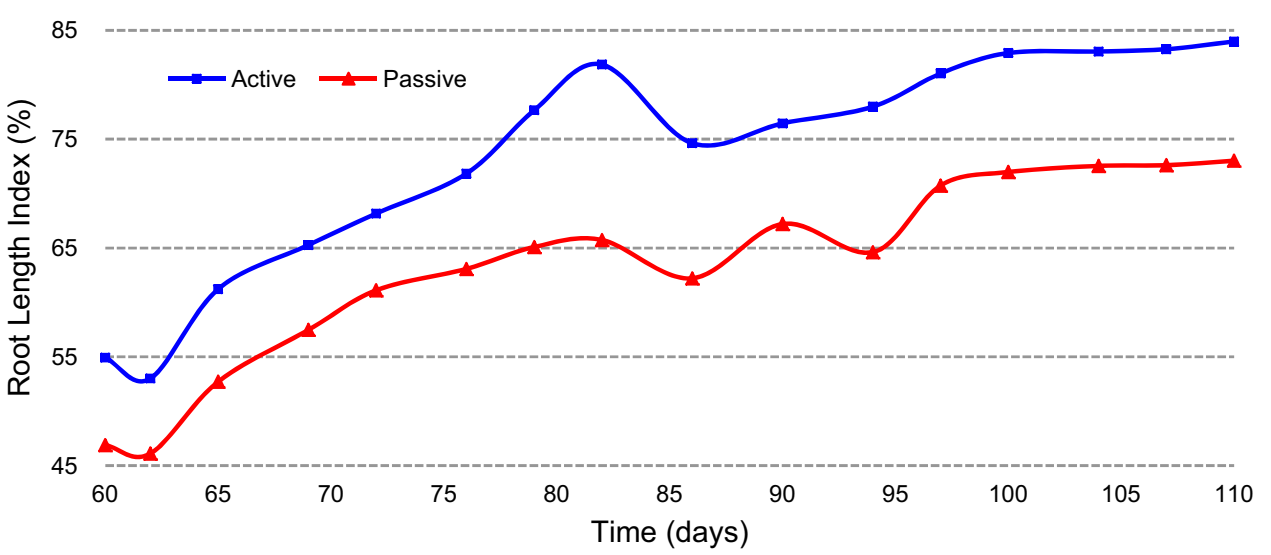


Fig. 7 Variation of phosphorus content during maturation period

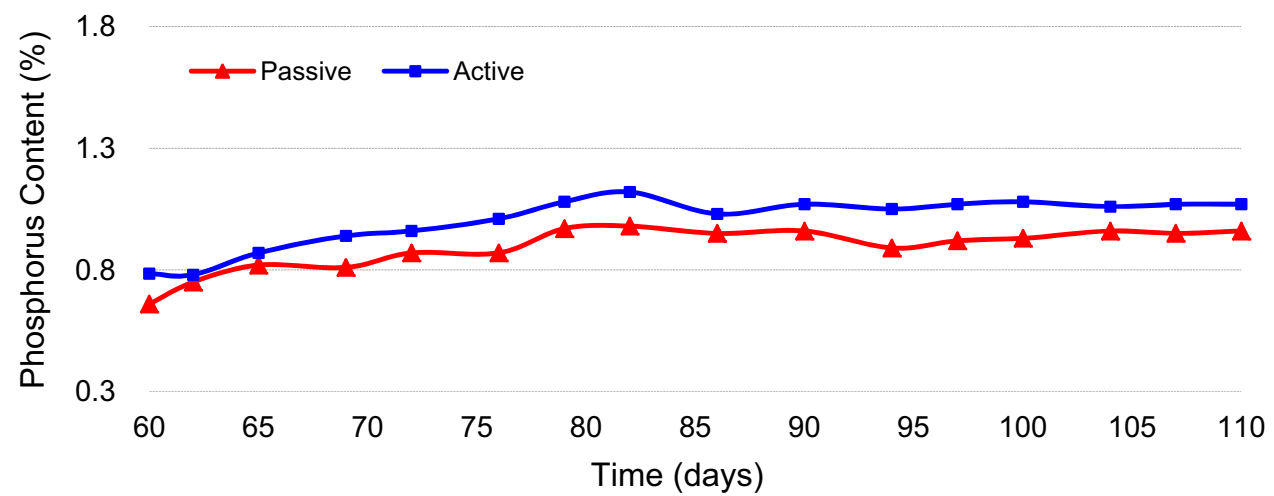

progressed, value of $1.03 \%$ and $0.90 \%$ were obtained in the final product from the respective reactors. Variations in the TKN contents during maturation period have been presented in Fig. 8.

\section{Potassium content}

The potassium content recommended by Fertilizer control order ranges from 0.60 to $1.14 \%$, minimum requirement being $1 \%$. The potassium content in the mulch of actively aerated reactor varied from 0.72 to $0.90 \%$ while in passively aerated reactor, it varied from 0.61 to $0.72 \%$, which were less than the recommended value of $1-2 \%$ for composts. This is attributed to its draining out in the form of leachate. However, because of additional air supply, the formation of leachate in actively aerated reactor was comparatively less than that in passively aerated reactor. Effective use of fibrous matter like straw or wood chips, which can absorb relatively large quantities of water and still maintain their structural integrity and porosity, could prevent the loss of potassium from the compost formed (Iyengar and Bhave 2006). Deviations in potassium content during maturation period have been illustrated in Fig. 9.

\section{Carbon/nitrogen ratio (C/N ratio)}

Carbon is the element that meets the energy requirements of microorganisms responsible for the evolution of the process, but at the same time, part of it becomes their basic structural component. Nitrogen is an integral part of proteins, nucleic acids, amino acids, and enzymes that are essential for the microbial growth of cells, accounting for $50 \%$ of their dry mass (Margaritis et al. 2018). Due to the high carbon content, the $\mathrm{C} / \mathrm{N}$ ratio was higher in both the study reactors. During maturation phase, the $\mathrm{C} / \mathrm{N}$ ratio was 36.06 in actively aerated reactors. The value reported was greater than the FCO standards. One of the ways suggested in the literature to reduce high $\mathrm{C} / \mathrm{N}$ ratio is, adding a nitrogenous waste, in a predetermined proportion (Diaz 2007). The higher value of $\mathrm{C} / \mathrm{N}$ ratio in passively aerated reactor as compared to the recommended $\mathrm{C} / \mathrm{N}$ ratio indicated that the mulch in the passive reactor require around 2 more weeks of time to get mature. Variations in $\mathrm{C} / \mathrm{N}$ ratio have been presented in Figs. 10, 11.

\section{Conclusion}

Composting of household biodegradable wastes was studied with active and passive aeration. The mulch from the actively aerated reactor showed a higher value of the $\mathrm{C} / \mathrm{N}$
Fig. 8 Variation of Total Kjeldahl Nitrogen during maturation period

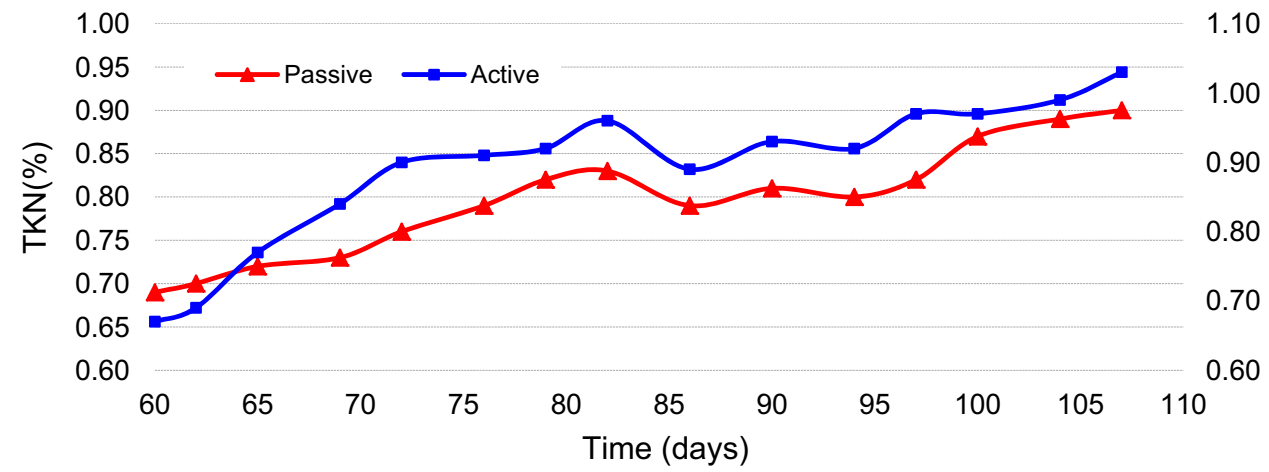


Fig. 9 Variation of potassium content during maturation period
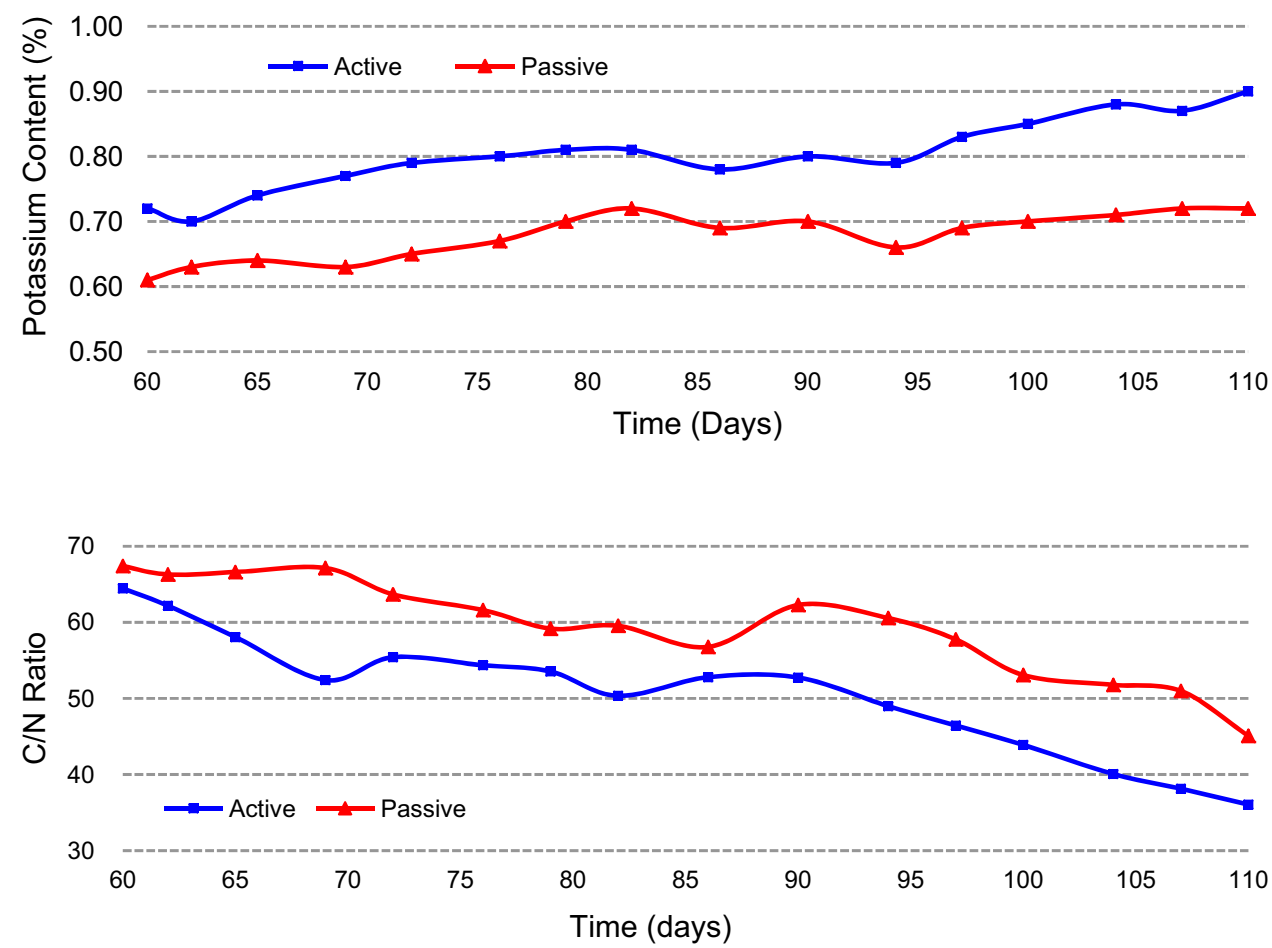

Fig. 10 Variation of $\mathrm{C} / \mathrm{N}$ ratio during maturation period

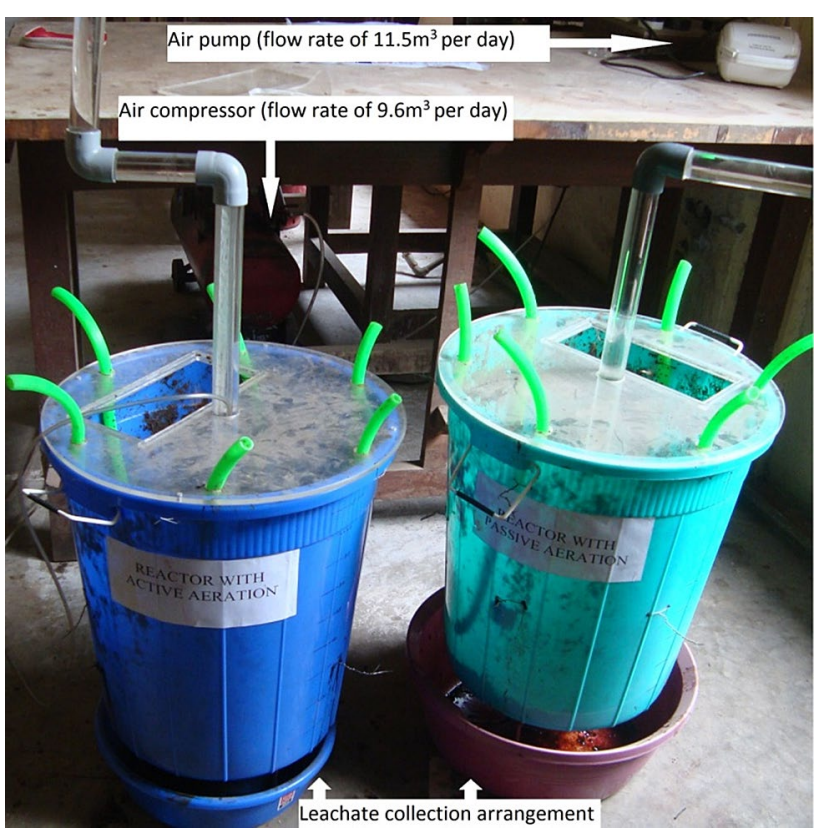

Fig. 11 Arrangement of Active and Passive reactors in the laboratory, at V J Technological Institute; Mumbai, India

ratio. The result suggests pre-evaluation of waste characteristics in terms of carbon and nitrogen contents and designing the reactor-loading to maintain the required $\mathrm{C} / \mathrm{N}$ ratio for good quality compost. Washing and shredding of the waste in uniform particle size, prior to loading into the reactor will improve overall quality of the final product from the reactors. The passively aerated reactor was not successful to perform as a household reactor because of the poor quality of the mulch.

The quality of compost from actively aerated reactor was found to be better on parameters such as Germination Index (81.72\%), Root Length Index (83.98\%), $N(1.02 \%)$, $P(1.02 \%)$ and $K(0.90 \%)$ values. The maturation period required for actively aerated reactor was reduced by $37.30 \%$ (almost one-third of the maturation time). In addition, the actively aerated reactor was found to be suitable on qualitative parameters such as odor, fly nuisance, and easy operation at the household level.

Open Access This article is distributed under the terms of the Creative Commons Attribution 4.0 International License (http://creativeco mmons.org/licenses/by/4.0/), which permits unrestricted use, distribution, and reproduction in any medium, provided you give appropriate credit to the original author(s) and the source, provide a link to the Creative Commons license, and indicate if changes were made.

\section{References}

Arrigoni JP, Paladino G, Garibaldi LA, Laos F (2018) Inside the small-scale composting of kitchen and garden waste: thermal performance and stratification effect in vertical compost bins. Waste Manag 76:284-293. https://doi.org/10.1016/j.wasma n.2018.03.010 
Bhave PP, Joshi YS (2017) Accelerated in-vessel composting for household waste. J Inst Eng India Ser A 98:367-376. https://doi. org/10.1007/s40030-017-0258-3

Central Public Health and Environment Engineering Organization (2016) Government of India. Manual on Municipal Solid Waste Management and Handling Rules, New Delhi

de Bertoldi M, Rutili A, Citterio B, Civilini M (1988) Composting management: a new process control through $\mathrm{O}_{2}$ feedback. Waste Manag Res 6:239-259. https://doi.org/10.1177/0734242X8800600141

Desai SN, Shah MA (2018) Decentralized solid waste management in urban areas: a review. Int J Curr Eng Technol 8:21-23. https://doi. org/10.14741/ijcet.v8i01.10881

Diaz LF, Bertoldi M de, Bidlingmaier W, Stentiford E (2007) Compost science and technology. Waste management series, vol 8. Elsevier. ISBN: 9780080439600

FAI (2007) The fertilizer control order 1985. The Fertilizer Association of India, New Delhi

Finstein MS, Hogan JA (1993) Integration of composting process microbiology, facility structure and decision-making. In: Hoitink $\mathrm{H}$, Keener $\mathrm{H}$ (eds) Science and engineering of composting: design, environmental, microbiological and utilization aspects. The Ohio State University, Columbus, p 728

Finstein MS, Miller FC, Storm PF, MacGregor ST, Psarianos KM (1983) Composting ecosystem management for waste treatment. Nat Biotechnol 1:347-353. https://doi.org/10.1038/nbt0683-347

Francou C, Poitrenaud M, Houot S (2005) Stabilization of organic matter spring compost: influence of process and feedstocks. Compost Sci Util 13(1):72-83. https://doi.org/10.1080/10656 57X.2005.10702220

Furedy C (1992) Garbage: exploring non-conventional options in Asian cities. Environ Urban 4:42-61. https://doi.org/10.1177/09562 4789200400205

Guo R, Li G, Jiang T, Schuchardt F, Chen T, Zhao Y, Shen Y (2012) Effect of aeration rate, $\mathrm{C} / \mathrm{N}$ ratio and moisture content on the stability and maturity of compost. Bioresour Technol 112:171-178. https://doi.org/10.1016/j.biortech.2012.02.099

Haug RT (1993) The practical handbook of compost engineering, 1st edn. CRC Press Lewis, Boca Raton

Iyengar SR, Bhave PP (2006) In-vessel composting of household wastes. Waste Manag 26(10):1070-1080. https://doi. org/10.1016/j.wasman.2005.06.011

Letcher T, Vallero D (2011) Waste: a handbook for management, 1st edn. Elsevier. https://doi.org/10.1016/C2009-0-60930-2

Ma J, Zhang L, Li A (2016) Energy-efficient co-biodrying of dewatered sludge and food waste: synergistic enhancement and variables investigation. Waste Manag 56:411-422. https://doi.org/10.1016/j. wasman.2016.06.007

Mandal P, Chaturvedi MK, Bassin JK, Vaidya AN, Gupta RK (2014) Qualitative assessment of municipal solid waste compost by indexing method. Int J Recycl Org Waste Agric 3(4):133-139. https://doi.org/10.1007/s40093-014-0075-x

Margaritis M, Psarras K, Panaretou V, Thanos AG, Malamis D, Sotiropoulos A (2018) Improvement of home composting process of food waste using different minerals. Waste Manag 73:87-100. https://doi.org/10.1016/j.wasman.2017.12.009

Mengistu T, Gebrekidan H, Kibret K, Woldetsadik K, Shimelis B, Yadav H (2017) Comparative effectiveness of different composting methods on the stabilization, maturation and sanitization of municipal organic solid wastes and dried faecal sludge mixtures. Environ Syst Res 6:5. https://doi.org/10.1186/s40068-017-0079-4

Paredes C, Cegarr J, Bernal MP, Roig A (2005) Influence of olive mill wastewater in composting and impact of the compost on a Swiss chard crop and soil properties. Environ Int 31:305-312. https:// doi.org/10.1016/j.envint.2004.10.007

Ravi Kumar P, Jayaram A, Somshekar RK (2009) Assessment of the Performance of different compost models to manage urban household organic solid wastes. Clean Technol Environ Policy 11(4):473-484. https://doi.org/10.1007/s10098-009-0204-9

Sanchez OJ, Ospina DA, Montoya S (2017) Compost supplementation with nutrients and microorganisms in composting process. Waste Manag 69:136-153. https://doi.org/10.1016/j.wasma n.2017.08.012

Schulze KL (1960) Rate of oxygen consumption and respiratory quotients during the aerobic decomposition of synthetic garbage. Compost Sci 1:36-40

Schulze KL (1961) Relationship between moisture content and activity of finished compost. Compost Sci 2:32-34

Sharma A, Ganguly R, Gupta A (2019) Spectral characterization and quality assessment of organic compost for agricultural purposes. Int J Recycl Org Waste Agric 8(2):197-213. https://doi. org/10.1007/s40093-018-0233-7

Shimizu N (2017) Process optimization of composting systems. In: Zhang D, Wei B (eds) Robotics and mechatronics for agriculture. CRC Press, Taylor \& Francis, pp 1-22. https://doi. org/10.1201/9781315203638-1

Stabnikova O, Ding HB, Tay JH, Wang JY (2005) Biotechnology for aerobic conversion of food waste into organic fertilizer. Waste Manag Res 23:39-47. https://doi.org/10.1177/0734242X0504976 8

Stentiford EI (1993) Diversity of composting systems. In: Hoitink H, Keener $\mathrm{H}$ (eds) Science and engineering of composting: design, environmental, microbial and utilization aspects. The Ohio State University, Renaissance Publications, Ohio, pp 95-110

Sundberg C, Yu D, Franke-Whittle I, Kauppi S, Smars S, Insam H, Romantschuk M, Jonsson H (2013) Effect of pH and microbial composition on odour in food waste composting. Waste Manag 33:204-211. https://doi.org/10.1016/j.wasman.2012.09.017

Suthar S, Singh P (2015) Household solid waste generation and composition in different family size and socio-economic groups: a case study. Sustain Cities Soc 14:56-63. https://doi.org/10.1016/j. scs.2014.07.004

USEPA (United States Environmental Protection Authority) Pathogen Equivalency Committee (PEC) (1999) Control of pathogens and vector attraction in sewage sludge. In: USEPA Environmental Regulations and Technology, Office of Research and Development EPA/625/R-92/013, Washington, DC, p 177

Vazquez MA, Sen R, Soto M (2015) Physico-chemical and biological characteristics of compost from decentralized composting programmes. Bioresour Technol 198:520-532. https://doi. org/10.1016/j.biortech.2015.09.034

Villar I, Alves D, Garrido J, Mato S (2016) Evolution of microbial dynamics during the maturation phase of the composting of different types of waste. Waste Manag 54:83-92. https://doi. org/10.1016/j.wasman.2016.05.011

Wu L, Ma LQ, Martinez GA (2000) Comparison of methods for evaluating stability and maturity of bio-solids compost. J Environ Qual 29:424-429. https://doi.org/10.2134/jeq2000.004724250029000 $20008 x$

Xiao Y, Zeng G-M, Yang Z-H, Shi W-J, Huang C, Fan C-Z, Xu Z-Y (2009) Continuous thermophilic composting (CTC) for rapid biodegradation and maturation of organic municipal solid waste. $\mathbf{J}$ Bioresour Technol 100(20):4807-4813. https://doi.org/10.1016/j. biortech.2009.05.013

Zurbrugg C, Drescher S, Patel A, Sharatchandra HC (2004) Decentralized composting of urban waste-an overview of community and private initiatives in Indian cities. Waste Manag 24(7):655-662. https://doi.org/10.1016/j.wasman.2004.01.003

Publisher's Note Springer Nature remains neutral with regard to jurisdictional claims in published maps and institutional affiliations. 